\title{
THE IMPACT OF LONG CANYON DESIGN AND WATERFRONT BARRIER BUILdings ON Wind Velocity In A CoAstal AREA Of SelatPanjang City
}

\section{Pengaruh Panjang Desain Canyon Dan Bangunan Penghalang Tepi Air Terhadap Perubahan Kecepatan Angin Di Daerah Pesisir Kota Selatpanjang}

\author{
Boby Rahman ${ }^{1}$, Ima Defiana ${ }^{2}$, Asri Dinapradipta ${ }^{3}$ \\ Departemen Arsitektur, FADP, Institut Teknologi Sepuluh Nopember ${ }^{1}$ \\ bobrdarchitect@gmail.com \\ Departemen Arsitektur, FADP, Institut Teknologi Sepuluh Nopember ${ }^{2}$ \\ Departemen Arsitektur, FADP, Institut Teknologi Sepuluh Nopember ${ }^{3}$
}

\begin{abstract}
:
The increase of waterfront buildings' height has an effect on wind distribution in the urban canyon. On the other hand, the distribution of wind is needed in providing thermal balance in urban environments, especially in urban waterfront coastal areas. This study aimed at observing and analyzing the effect of building height $(H)$ on waterfront buildings and aspects of the length to width $(L / W)$ ratio related to the length of the canyon design. The observation was focused on the wind speed distribution. The research was an experimental research using ENVI-met V3.1 software for simulation. The results indicated that short canyon (low $L / W$ value) results in lower wind speed changes compared to that of long one (higher $L / W$ value) at all altitude levels. The short canyons provided more stability in wind speed reduction. The 15 meters wide of canyon design contributed to the highest average wind speed. Overall, the existence of a barrier building would result in a negative area of air flow and create a calm area within the distance of \pm 50 meters.
\end{abstract}

Keyword: $L / W$ ratio, waterfront barrier buildings, wind velocity, urban canyon

\section{PENDAHULUAN}

Meningkatnya fungsi kawasan pada Kota Selatpanjang menyebabkan munculnya bangunan-bangunan dengan ketinggian yang berbeda. Kondisi tersebut menyebabkan terhalangnya distribusi angin pada lingkungan canyon perkotaan. Sementara itu, kebutuhan akan pendinginan melalui aliran udara sangat dibutuhkan seiring perubahan fisik kota terutama pada perubahan penggunaan lahan yang dapat mengarah terjadinya fenomena urban heat island (UHI) (Cha dkk, 2007). Dari penjelasan tersebut diatas, penelitian ini menganalisa perubahan kecepatan angin yang dipengaruhi oleh geometri tinggi bangunan $(H)$ pada bangunan penghalang tepi air dan pengaruh rasio $L / W$ terkait panjang desain canyon terhadap perubahan kecepatan angin. Canyon disini merupakan ruang linier diantara bangunan yang berperan sebagai ventilasi perkotaan (Erell dkk, 2011). Ruang linier yang dimaksud merupakan panjang dari desain canyon. Pemaknaan panjang desain canyon menurut Ahmad, dkk (2005) yaitu panjang desain canyon dimulai dari persimpangan dan berakhir pada pesimpangan berikutnya dengan terputusnya bangunan dikedua sisi jalan. 
Aliran angin didalam desain canyon dibagi menjadi 2, yaitu: 1) Urban canopy layer; 2) Urban boundary layer. Urban canopy layer berada pada ketinggian dekat dari permukaan jalan (pedestrian), sedangkan urban boundary layer berada pada ketinggian rata-rata bangunan perkotaan. Pada kondisi urban canopy layer kecepatan angin lebih rendah karena adanya tingkat friksi yang tinggi oleh bangunan, pohon, dan aktivitas yang ada didalam desain canyon bangunan (Thomas dkk, 2003). Pada penelitian Hang, dkk (2010) menemukan canyon yang lebih panjang mengakibatkan kecepatan angin lebih rendah pada level pedestrian. Al sallal, dkk (2012) menemukan desain canyon yang sempit $(4 \mathrm{~m}$ dan kurang dari 4m) dapat meningkatkan kecepatan aliran udara sehingga menghasilkan pendinginan pasif yang lebih baik. Hal berbeda disampaikan oleh Chan, dkk (2001) yang mengatakan bahwa perkotaan yang memiliki lebar jalan yang lebih luas (W besar) dapat memberikan distribusi aliran udara yang baik. Terkait bangunan penghalang, Aynsley (1977) menjelaskan bahwa, pergerakan udara di lingkungan luar dipengaruhi oleh keberadaan penghalang seperti bangunan yang terbentuk karena adanya kombinasi bentuk, ketinggian dan jarak pada karakter tapak tertentu. Boutet (1987) mengatakan perbandingan bangunan dengan panjang dan lebar yang sama, namun memiliki ketinggian yang berbeda menghasilkan aliran Eddy dan zona tenang yang lebih panjang. Hal tersebut dipengaruhi oleh loncatan aliran angin yang terjadi pada bagian atas bangunan, sehingga aliran angin membutuhkan jarak yang lebih panjang untuk kembali pada aliran normalnya. Pada penelitian Priyadarsini, dkk (2005) menyatakan adanya beberapa bangunan tinggi dari bangunan lainnya dapat meningkatkan kecepatan aliran udara hingga $90 \%$ untuk aliran paralel dan dapat meningkat jika aliran tegak lurus.

\section{METODE PENELITIAN}

Penelitian ini merupakan penelitian eksperimental menggunakan simulasi software ENVI-met V3.1. Pengaruh geometri bangunan terhadap angin dibagi menjadi 2 pengamatan, yaitu: 1) pengamatan panjang desain canyon melalui kajian aspek rasio $L / W$ (Tabel 1);2) pengamatan bangunan penghalang tepi air
(Tabel 2). Dua pengamatan yang dilakukan tidak saling terkait karena perbedaan fokus pengamatan yang dilakukan. Pada eksperimen kelompok 1 fokus terhadap pengaruh variasi desain lebar jalan $(W)$ pada panjang desain canyon 104 meter terhadap perubahan kecepatan angin pada level urban canopy layer (pedestrian) dan pada level urban boundary layer (Gambar 1). Sedangkan pada model eksperimen kelompok 2 fokus kepada perubahan skematik aliran angin yang dipengaruhi oleh variasi ketinggian bangunan penghalang tepi air yang juga diamati pada level urban canopy layer (ketinggian $1.5 \mathrm{~m}$ ) dan pada level urban boundary layer (ketinggian $12.5 \mathrm{~m}$ ). Sampel penelitian merupakan salah satu jalan utama Kota Selatpanjang bagian barat yaitu jalan Imam Bonjol (Gambar 2).

Tabel 1. Model rancangan eksperimen kelompok 1

\begin{tabular}{|c|l|c|c|c|c|}
\hline \multirow{2}{*}{ No } & \multirow{2}{*}{$\begin{array}{l}\text { Kondisi } \\
\text { bangunan }\end{array}$} & \multicolumn{3}{|c|}{ Aspek rasio } & \multirow{2}{*}{$\begin{array}{c}\text { Kode } \\
\text { model }\end{array}$} \\
\cline { 3 - 6 } 1 & & $\mathrm{~L}$ & $\mathrm{~W}$ & $\mathrm{~L} / \mathrm{W}$ & \\
\hline \multirow{2}{*}{1} & \multirow{2}{*}{$\begin{array}{l}\text { Ketinggian } \\
\text { bangunan 15 } \\
\text { meter }\end{array}$} & 104 & 17 & 6.11 & $1 \mathrm{~A}$ \\
\cline { 3 - 6 } & & 104 & 5 & 20.8 & $1 \mathrm{~B}$ \\
\cline { 3 - 6 } & $\begin{array}{l}\text { Ketinggian } \\
\text { bangunan 7 } \\
\text { meter }\end{array}$ & 104 & 13 & 8 & $1 \mathrm{C}$ \\
\cline { 3 - 6 } & 104 & 104 & 5 & 20.8 & $2 \mathrm{~B}$ \\
\cline { 3 - 6 } & & 13 & 8 & $2 \mathrm{C}$ \\
\hline
\end{tabular}
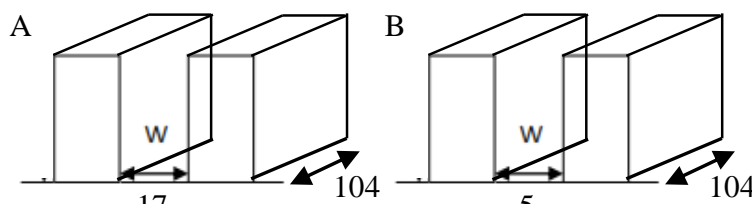

17

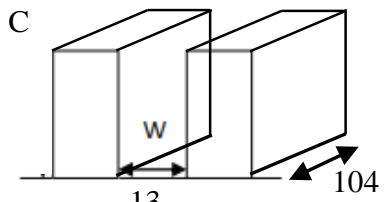

Gambar 1. Ilustrasi Model Eksperimen Kelompok 1

Tabel 2. Model Rancangan Eksperimen Kelompok 2

\begin{tabular}{|c|l|c|}
\hline No & Kondisi bangunan penghalang & $\begin{array}{c}\text { Kode } \\
\text { model }\end{array}$ \\
\hline 1 & $\begin{array}{l}\text { Bangunan penghalang tepi air 7 } \\
\text { meter }\end{array}$ & $1 \mathrm{~A}$ \\
\hline 2 & $\begin{array}{l}\text { Bangunan penghalang tepi air 15 } \\
\text { meter (Kondisi terkini) }\end{array}$ & $2 \mathrm{~A}$ \\
\hline
\end{tabular}




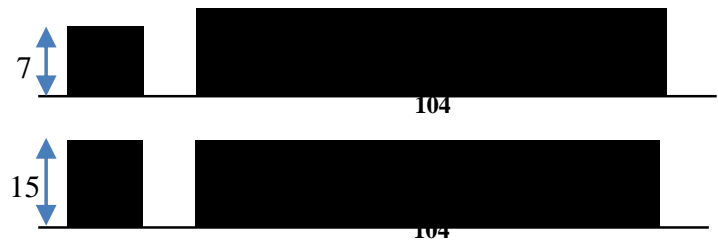

Gambar 2. Ilustrasi Model Eksperimen Kelompok 2

Titik pengamatan pada eksperimen terdapat 5 titik pengamatan yang di beri nama $\mathrm{T} 1, \mathrm{~T} 2, \mathrm{~T} 3$, T4, dan T5 (Gambar 3). Jarak masing-masing titik pengamatan didalam panjang desain canyon 104 m yaitu 25 meter yang disamakan melalui titik koordinat pada software ENVI-met v3.1.

Kota Selatpanjang memiliki 3 jalan utama yang berorientasi utara-selatan. Jalan tersebut memanjang dari tepi pantai menuju ke area daratan (daerah pengembangan) dengan radius $2.5 \mathrm{~km}$ (Gambar 4).

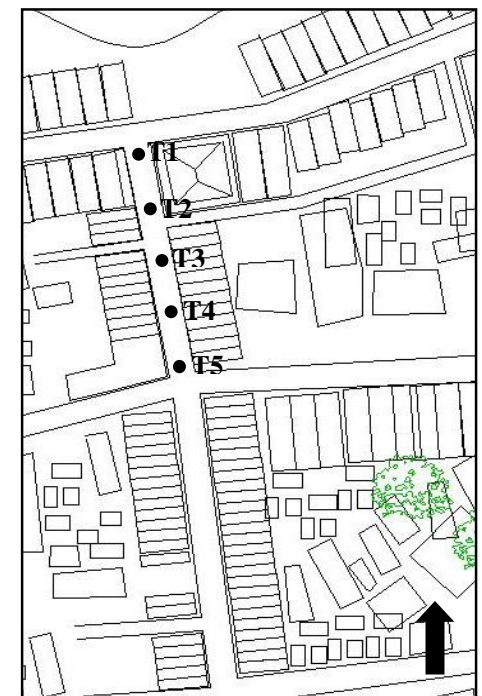

Gambar 3. Lima titik pengamatan

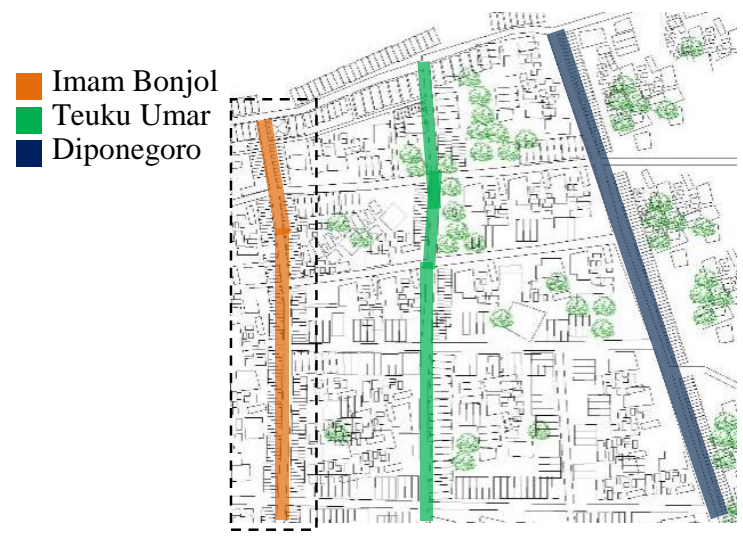

Gambar 4. Tiga jalan utama Kota Selatpanjang
Pemilihan jalan Imam bonjol terpilih berdasarkan tingkat kepadatan (pengguna jalan dan bangunan). Jalan Imam bonjol memiliki tingkat kepadatan pengguna jalan yang paling tinggi diantara dua jalan yang lainnya. Hal tersebut dikarenakan jalan Imam bonjol merupakan pusat kegiatan ekonomi yang ada di Kota Selatpanjang (Gambar 5).
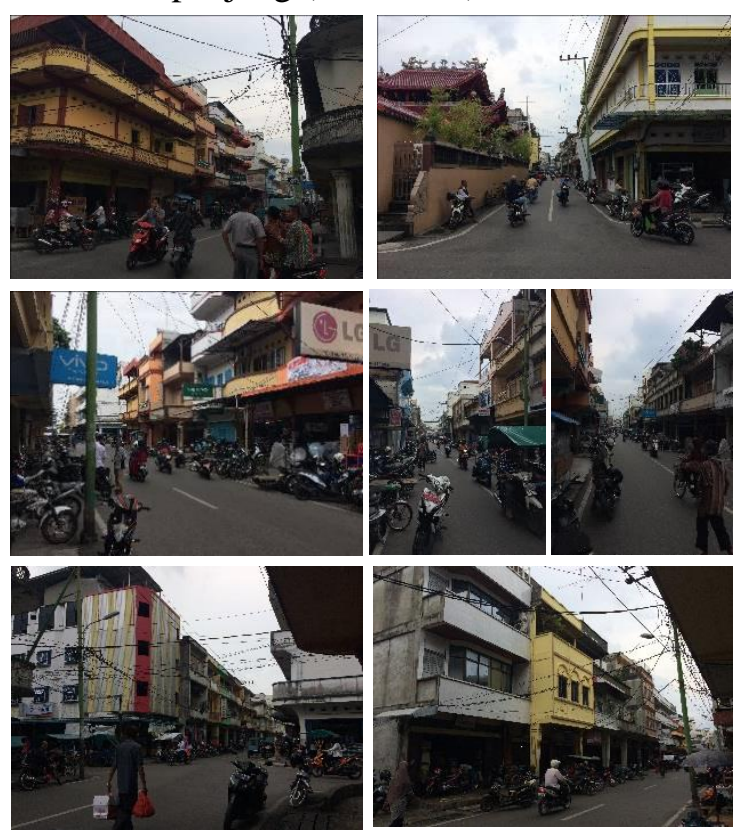

Gambar 5. Situasi jalan Imam bonjol

\section{HASIL DAN DISKUSI}

3.1 Pengaruh Rasio $L / W$ terhadap Perubahan Kecepatan Angin pada Ketinggian Bangunan 15 meter

Ketinggian bangunan 4 lantai merupakan peraturan yang ditetapkan oleh pemerintah daerah Kota Selatpanjang no 09 (2015) tentang ketinggian bangunan usaha yang tertata berderet dan berdempet. Dari hasil penelitian, desain canyon yang lebih panjang ( $L / W 20.8$ ) pada model 1B akan mengakibatkan perubahan kecepatan aliran udara lebih tinggi pada level urban canopy layer dibandingkan desain canyon pendek dengan selisih $0.02 \mathrm{~m} / \mathrm{s}$. Hal tersebut berbeda dengan penelitian Hang, dkk (2010) yang mengatakan L/W 333 (desain canyon panjang) menghasilkan perubahan kecepatan aliran udara yang lebih rendah pada level urban canopy layer. L/W 6.11 dengan desain lebar jalan (W) 17 meter pada model 1A memiliki perubahan kecepatan aliran udara rata-rata pada level urban boundary layer sebesar $0.675 \mathrm{~m} / \mathrm{s}$ dan pada level urban canopy 
layer sebesar $0.61 \mathrm{~m} / \mathrm{s}$. Perubahan terbesar terjadi pada titik pengamatan $\mathrm{T} 1$ menuju $\mathrm{T} 2$ sebesar $1.46 \mathrm{~m} / \mathrm{s}$ (urban boundary layer) dan $1.3 \mathrm{~m} / \mathrm{s}$ (urban canopy layer). Selanjutnya pada titik pengamatan T2 hingga ke T5 tidak memiliki selisih yang besar. Pada L/W 20.8 dengan desain lebar jalan (W) 5 meter pada model 1B memiliki perubahan kecepatan aliran udara rata-rata pada level urban boundary layer sebesar $0.53 \mathrm{~m} / \mathrm{s}$ dan pada level urban canopy layer sebesar $0.63 \mathrm{~m} / \mathrm{s}$. Berikutnya pada model 1C dengan L/W 8 (desain lebar jalan (W) 13 meter) memiliki perubahan kecepatan aliran udara rata-rata pada level urban boundary layer sebesar $0.83 \mathrm{~m} / \mathrm{s}$ dan pada level urban canopy layer sebesar $0.74 \mathrm{~m} / \mathrm{s}$. Sama hal nya dengan model 1A, model 1B dan 1C juga memiliki perubahan kecepatan aliran udara tertinggi pada titik pengamatan $\mathrm{T} 1$ menuju $\mathrm{T} 2$.

Tabel 3. Perubahan rata-rata kecepatan angin

\begin{tabular}{|c|c|c|c|}
\hline \multirow{2}{*}{ Level } & \multicolumn{3}{|c|}{$\begin{array}{c}\text { Rata-rata penurunan } \\
\text { kecepatan angin }\end{array}$} \\
\cline { 2 - 4 } & $1 \mathrm{~A}$ & $1 \mathrm{D}$ & $1 \mathrm{~F}$ \\
\hline $\begin{array}{c}\text { Urban canopy } \\
\text { layer }\end{array}$ & $0,61 \mathrm{~m} / \mathrm{s}$ & $0,63 \mathrm{~m} / \mathrm{s}$ & $0.74 \mathrm{~m} / \mathrm{s}$ \\
\hline $\begin{array}{c}\text { Urban boundary } \\
\text { layer }\end{array}$ & $0.67 \mathrm{~m} / \mathrm{s}$ & $0.53 \mathrm{~m} / \mathrm{s}$ & $0.83 \mathrm{~m} / \mathrm{s}$ \\
\hline
\end{tabular}

Secara keseluruhan dari hasil penelitian, Desain $W$ yang lebar pada desain canyon menghasilkan kecepatan angin yang tinggi yaitu pada model 1A dengan $(W) 17$ meter dibandingkan model $1 \mathrm{~B}$ dan $1 \mathrm{C}$ yang masing-masing memiliki lebar jalan (W) 5 dan 13 meter (Gambar 6, 7, 8). Hal tersebut berbeda dengan penelitian Al sallal, dkk (2012) yang menemukan desain jalan (W) yang sempit menghasilkan kecepatan angin yang tinggi.

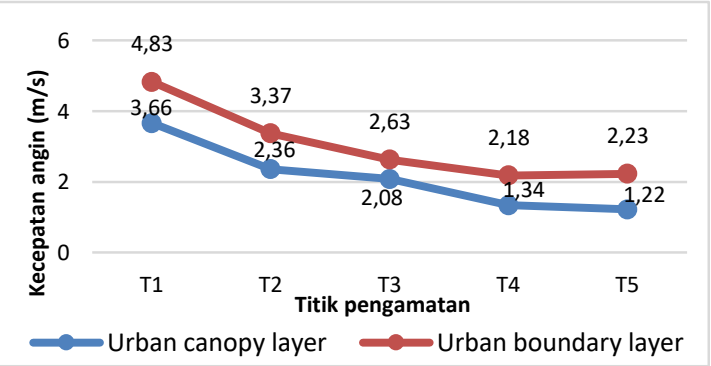

Gambar 6. Perubahan Kecepatan Angin Model 1A

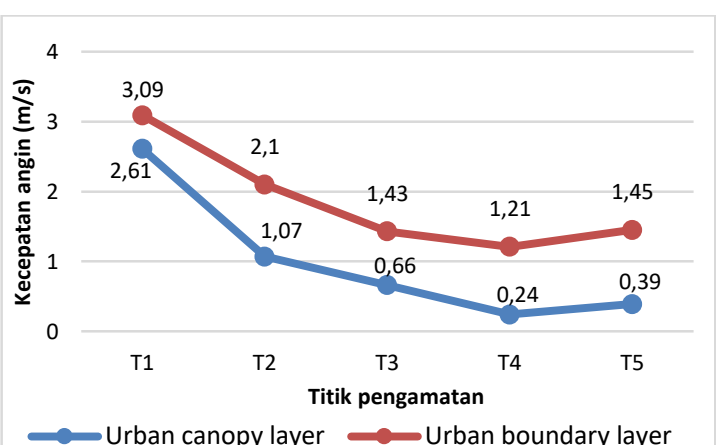

Gambar 7. Perubahan Kecepatan Angin Model 1B

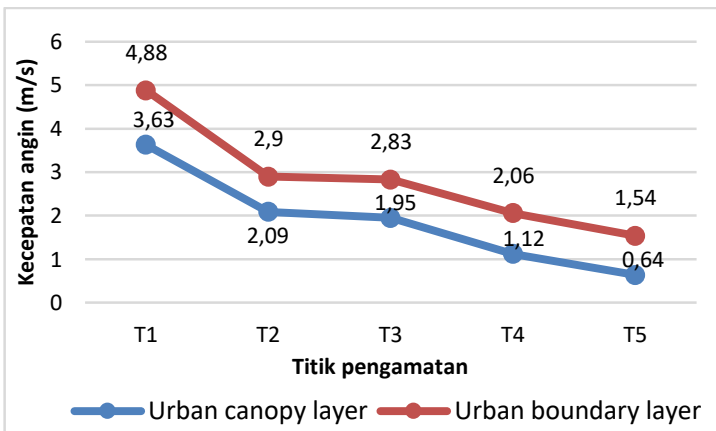

Gambar 8. Perubahan kecepatan angin model 1C

\subsection{Pengaruh Rasio $L / W$ terhadap Perubahan Kecepatan Angin pada Ketinggian Bangunan 2 Lantai}

Sama hal nya dengan kondisi yang terjadi pada model pada ketinggian bangunan 15 meter, model dengan desain $W$ yang besar memiliki kecepatan angin yang lebih tinggi jika dibandingkan dengan desain canyon yang memiliki desain $W$ yang kecil. Hal tersebut dikarenakan pada penelitian ini kecepatan angin dominan berasal dari orientasi utaraselatan sehingga pengaruh rasio $L / W$ memiliki peran yang besar terhadap perubahan kecepatan angin. $L / W 6.11$ dengan desain lebar jalan (W) 17 meter pada model $2 \mathrm{~A}$ memiliki perubahan kecepatan angin rata-rata pada level urban canopy layer sebesar $0.33 \mathrm{~m} / \mathrm{s}$ dan pada level urban boundary layer sebesar $0.34 \mathrm{~m} / \mathrm{s}$ (Tabel 4).

Tabel 4. Perubahan Rata-Rata Kecepatan Angin

\begin{tabular}{|c|c|c|c|}
\hline \multirow{2}{*}{ Level } & \multicolumn{3}{|c|}{$\begin{array}{c}\text { Rata-rata penurunan } \\
\text { kecepatan angin }\end{array}$} \\
\cline { 2 - 4 } & $2 \mathrm{~A}$ & $2 \mathrm{~B}$ & $2 \mathrm{C}$ \\
\hline $\begin{array}{c}\text { Urban canopy } \\
\text { layer }\end{array}$ & $0,33 \mathrm{~m} / \mathrm{s}$ & $0,5 \mathrm{~m} / \mathrm{s}$ & $0.71 \mathrm{~m} / \mathrm{s}$ \\
\hline $\begin{array}{c}\text { Urban boundary } \\
\text { layer }\end{array}$ & $0.34 \mathrm{~m} / \mathrm{s}$ & $0.45 \mathrm{~m} / \mathrm{s}$ & $0.64 \mathrm{~m} / \mathrm{s}$ \\
\hline
\end{tabular}


Perubahan terbesar juga terjadi pada titik pengamatan T1 menuju T2 sebesar $0.87 \mathrm{~m} / \mathrm{s}$ (urban canopy layer) dan $0.83 \mathrm{~m} / \mathrm{s}$ (urban boundary layer) (Gambar 9). Selanjutnya pada titik pengamatan T2 hingga ke T5 tidak memiliki selisih yang besar. Pada $L / W 20.8$ dengan desain lebar jalan (W) 5 meter pada model 2B memiliki perubahan kecepatan angin rata-rata pada level urban canopy layer sebesar $0.5 \mathrm{~m} / \mathrm{s}$ dan pada level urban boundary layer sebesar $0.45 \mathrm{~m} / \mathrm{s}$ (Gambar 10). Berikutnya pada model 2C dengan L/W 8 (desain lebar jalan (W) 13 meter) memiliki perubahan kecepatan angin rata-rata pada level urban canopy layer sebesar $0.71 \mathrm{~m} / \mathrm{s}$ dan level urban boundary layer sebesar $0.64 \mathrm{~m} / \mathrm{s}$ (Gambar 11). Sama hal nya dengan model $2 \mathrm{~A}$, model $2 \mathrm{~B}$ dan $2 \mathrm{C}$ juga memiliki perubahan kecepatan angin tertinggi pada titik pengamatan T1 menuju T2.

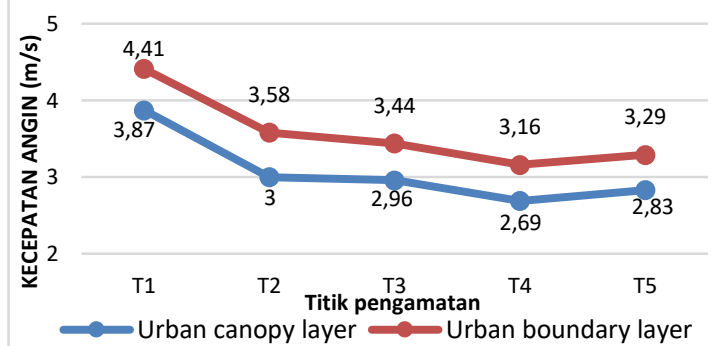

Gambar 9. Perubahan Kecepatan Angin Model 2A

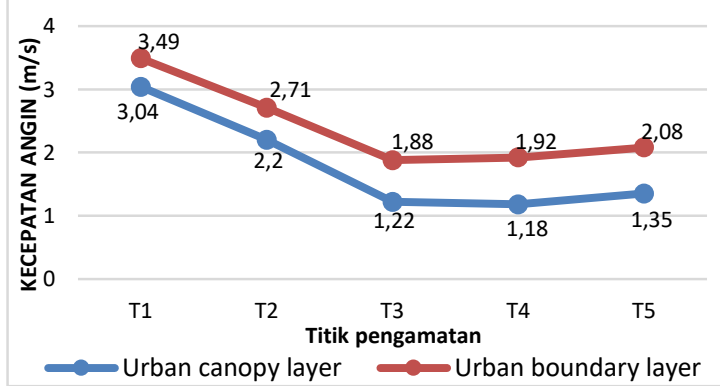

Gambar 10. Perubahan Kecepatan Angin Model 2B

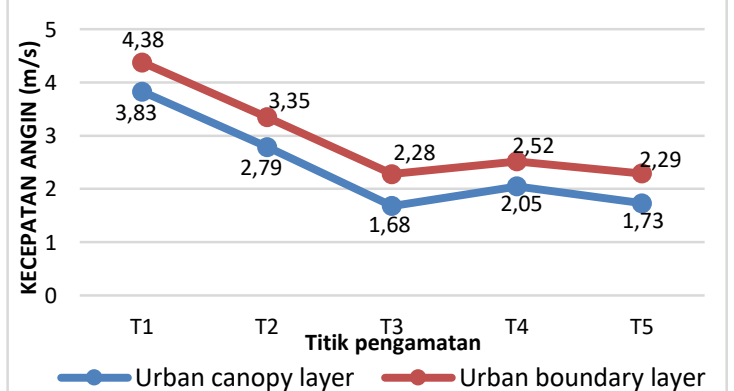

Gambar 11. Perubahan kecepatan angin model $2 \mathrm{C}$

\subsection{Pengaruh Bangunan Penghalang terhadap Perubahan Skematik Kecepatan Angin}

Perubahan yang diberikan terkait keberadaan bangunan penghalang 7 meter (model 2A, 2B, 2C) dan 15 meter (model 1A, 1B, 1C) memberikan perlakuan yang berbeda pada skematik aliran angin. Aliran angin pada model eksperimen 1 memiliki kecenderungan terus mengalami penurunan dari titik awal hingga ke titik ke 4 dan mulai naik pada titik ke 5 . Hal berbeda terjadi pada model eksperimen 2 yang dipengaruhi dua variasi ketinggian bangunan penghalang tepi air yaitu 7 meter dan 15 meter (kondisi terkini), dimana kecepatan angin pada titik awal (T1) memiliki nilai yang paling rendah. Pergerakan kecepatan angin dari T1 menuju T2 dan T3 terus mengalami kenaikan. Puncak kecepatan angin berada pada titik ke tiga (T3) dan kemudian kembali turun pada titik ke 4 (T4) dan pada titik ke 5 (T5) kembali mengalami kenaikan (Gambar 12, 13).

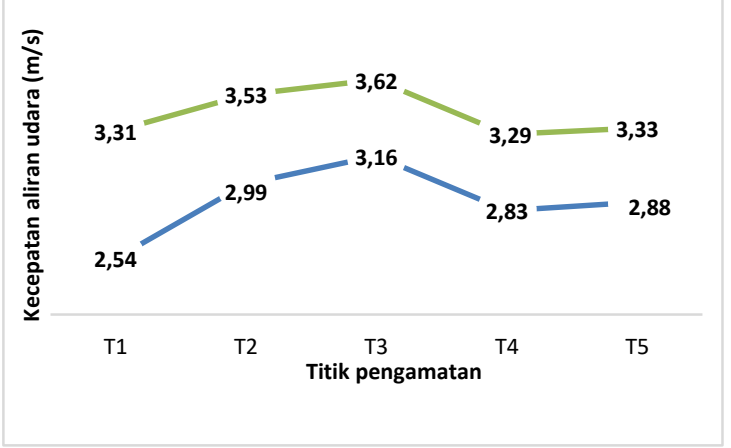

-Urban canopy layer $\quad$ Urban boundary layer Gambar 12. Skematik Perubahan Kecepatan Angin Model 1A

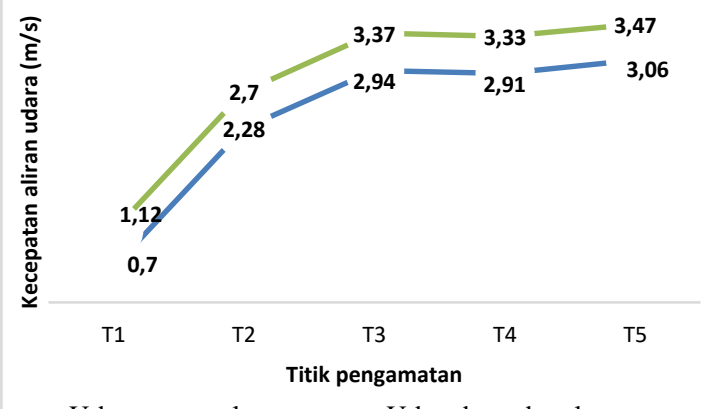

- Urban canopy layer - Urban boundary layer

Gambar 13. Skematik Perubahan Kecepatan Angin Model 2A

Pada kedua grafik terlihat bahwa kecepatan angin pada level urban boundary layer lebih tinggi jika dibandingkan level urban canopy layer. Hal demikian dikarenakan pada level urban canopy layer, adanya tingkat friksi yang tinggi oleh bangunan, pohon, dan aktivitas yang ada didalam desain canyon bangunan (Thomas 
dkk, 2003). Terjadinya perubahan skematik kecepatan angin yang telah dijelaskan diatas merupakan dampak dari perlakuan modifikasi ketinggian yang diberikan pada bangunan penghalang tepi air. Perbedaan skematik tersebut dikarenakan terjadinya perbedaan lompatan aliran angin ketika mengenai bangunan penghalang. Hal tersebut diatas terjadi pada semua level ketinggian. Seperti yang dijelaskan oleh Boutet (1987) dan Aynsley (1977) tentang proporsi bangunan dengan dimensi bayangan angin (leeward) dan olakan (eddy) yaitu semakin panjang dan semakin tinggi massa bangunan maka semakin besar dimensi bayangan angin dan olakan yang diperoleh (Gambar 14). Hal tersebut dipengaruhi oleh loncatan aliran angin yang terjadi pada bagian atas bangunan, sehingga aliran angin membutuhkan jarak yang lebih panjang untuk kembali pada aliran normalnya.

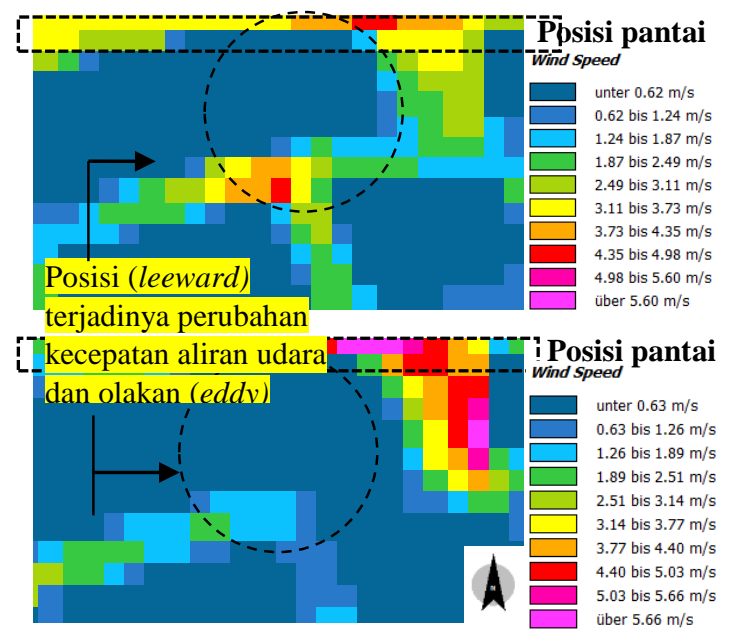

Gambar 14. Perbandingan Kecepatan Aliran Angin pada Posisi Leeward antara Model 1A dan $2 \mathrm{~A}$

Adanya bangunan penghalang menghasilkan desain canyon yang berorientasi barat-timur (Gambar 15). Akibat dari perbedaan ketinggian bangunan penghalang, kecepatan angin pada model 1A (ketinggian bangunan penghalang 7 meter) pada posisi leeward lebih tinggi jika dibandingkan dengan model 2A (ketinggian bangunan penghalang 15 meter). Hal tersebut dikarenakan lompatan aliran angin yang mengenai bangunan penghalang dibelokkan kebawah oleh bangunan yang lebih tinggi didepannya. Adanya ketinggian bangunan yang berbeda antara bangunan penghalang tepi air dan bangunan pada desain canyon memberi keuntungan pada desain canyon yang berorientasi barat-timur dan menghasilkan kenaikan temperatur udara sebesar $0.9{ }^{\circ} \mathrm{C}$ (Gambar 16). Seperti yang dikatakan Priyadarsini, dkk (2005) dan Chan, dkk (2001) bahwa adanya beberapa bangunan tinggi dari bangunan lainnya dapat meningkatkan kecepatan angin hingga 90\% untuk aliran paralel dan temperatur udara turun hingga $1{ }^{\circ} \mathrm{C}$. Pada aliran tegak lurus, kecepatan angin lebih meningkat dan temperatur udara turun $1.1^{\circ} \mathrm{C}$.

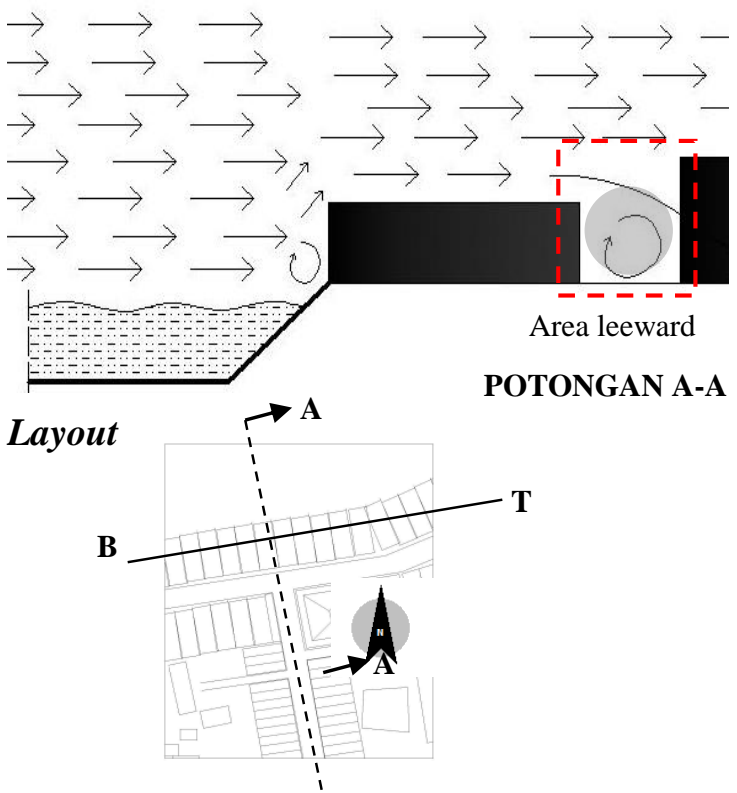

Gambar 15. Bangunan Penghalang Menciptakan Desain Canyon yang Berorientasi Barat-Timur

Lompatan aliran angin karena ketinggian bangunan penghalang mengakibatkan panjangnya area dengan kondisi tenang pada model 2A. Seperti yang dikatakan Boutet (1987) bahwa aliran angin yang mengalami lompatan karena terkena bangunan penghalang membutuhkan waktu untuk kembali pada posisi semula. Pada model 1A hal tersebut tidak terjadi karena kondisi bangunan penghalang yang rendah (JLB 2). Lompatan aliran angin akan cepat kembali pada posisi semula dibandingkan model 2A (ketinggian bangunan penghalang 15 meter). 


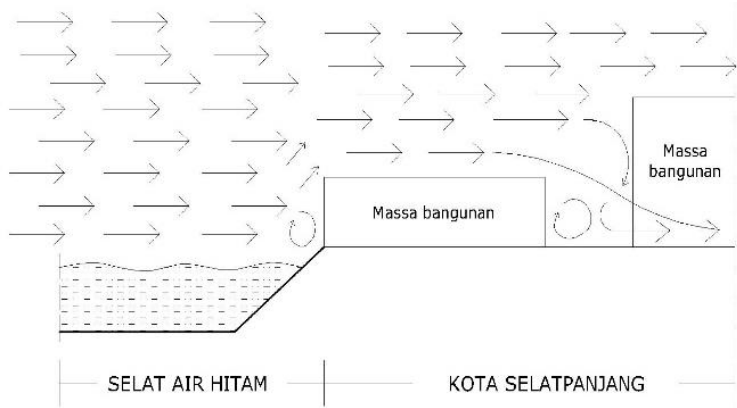

Gambar 16. Arah Aliran Udara Akibat Perbandingan Ketinggian Bangunan

\section{KESIMPULAN}

Pada kajian aspek rasio $L / W, L / W$ rendah (short canyon) dengan karakteristik (W) yang lebar pada Kota Selatpanjang menghasilkan perubahan kecepatan aliran udara yang lebih rendah pada semua ketinggian bangunan (JLB4 dan JLB2) dan semua level ketinggian (urban canopy layer dan urban boundary layer) jika dibandingkan dengan long canyon. Kondisi tersebut terus mengalami penurunan kecepatan aliran udara seiring berkurang lebar jalan $(W)$. Hal tersebut menunjukkan $L / W$ rendah (short canyon) lebih memiliki kestabilan didalam penurunan kecepatan aliran udara dibandingkan $L / W$ tinggi (long canyon). Penelitian ini berbeda dengan penelitian Hang, dkk (2010) yang mengatakan long canyon memiliki perubahan udara yang lebih rendah dibandingkan short canyon. Terjadinya perbedaan hasil tersebut dikarenakan adanya perbedaan aspek fisik (dimensi ketinggian bangunan dan lebar jalan) dan lokasi penelitian (pesisir dan pusat kota) serta perbedaan keterbatasan software simulasi yang digunakan. Jika dibandingkan dengan rata-rata kecepatan aliran udara pada JLB2, JLB4 memiliki kecepatan aliran udara lebih rendah disemua level ketinggian (urban canopy layer dan urban boundary layer). $L / W$ dengan karakteristik $(W)$ yang lebar yaitu 15 meter dan $(H) 7$ meter pada Kota Selatpanjang merupakan desain canyon yang menghasilkan kecepatan aliran udara rata-rata yang paling tinggi sehingga baik diterapkan pada Kota Selatpanjang sebagai salah satu langkah didalam mengimbangi tingginya kondisi termal perkotaan daerah pesisir.

Pada skematik aliran udara terkait dengan perbandingan desain canyon didalam kondisi dipengaruhi penghalang dan tidak dipengaruhi penghalang menghasilkan perbedaan yang signifikan pada skematik perubahan kecepatan aliran udara pada desain canyon. Pada desain canyon tanpa penghalang memiliki skema penurunan nilai kecepatan aliran udara yang teratur pada semua level ketinggian. Sedangkan pada desain canyon didalam kondisi dipengaruhi penghalang, terjadinya lompatan aliran udara karena mengenai bangunan penghalang menghasilkan daerah tenang sepanjang \pm 50 meter yaitu pada titik pengamatan $\mathrm{T} 1$ dan $\mathrm{T} 2$ yang merupakan area Leeward yang mengalami olakan (Eddy).

\section{REFERENSI}

Ahmad, K., M. Khare, and K. K., (2005), "Chaudhry, Wind tunnel simulation studies on dispersion at urban street canyons and intersections - a review," Journal of Wind Engineering and Industrial Aerodynamics, vol. 93, pp. 697717.

Al-Sallal, A., Al-Rais, L., (2012), "Outdoor airflow analysis and potential for passive cooling in the modern urban context of Dubai" Renewable Energy, vol.38, pp. 4049.

Aynsley, R.M, W. Melabourne dan Bj. Vockery, (1977), "Architectural Aeorodynamics", Applied Science Publisher: London.

Boutet, T., (1987), “Air Movement”, Mc Graw Hill Co., New York.

Cha, J.G., Jung, Eung-ho., Ryu, Ji-Won., Kim, Dae-Wuk., (2007), "Constructing a Green Network to Alleviate the Urban HeatIsland Phenomenon: Focusing on Daegu Metropolitan City in Korea", Real Corp 007 Proceddings, Tangungsband Vienna.

Chan A.T., E. S. P. So, and S. C. Samad, (2001), "Strategic guidelines for street canyon geometry to achieve sustainable street air quality, "Atmospheric Environment, vol.35, pp. 5681-5691, 2001.

Erell, E., Pearlmutter, D., Williamson, T.T.J., (2011), "Urban microclimate: designing the spaces between buildings", Routledge.

Hang, J., Yugou Li. Dan Mats Sandberg. (2010), "Wind conditions and ventilation in high-rise long street models". Building and Environment 45; 1353-1365. 
Priyadarsini, R., Wong, N., (2005) "Parametric studies on urban geometry, airflow and temperature" International journal on architectural science, vol. 6, no. 3, pp. 114-132.

Thomas, R., Fordham, M., (2003), "Sustainable Urban Design: An environmental approach". London and New York: E \& FN Spon. 